\title{
SIMULTANEOUS SPECTROPHOTOMETRIC DETERMINATION OF PHENOLIC ANTIOXIDANT (BHA AND BHT) CONCENTRATIONS IN PHARMACEUTICAL PREPARATIONS AND CHEWING GUMS USING THE H-POINT STANDARD ADDITION METHOD
}

\author{
Mahmure Özgürr*, Zeynep Kalaycığlu², Öznur Dülger ${ }^{1}$ \\ ${ }^{1}$ Ylldiz Technical University, Faculty of Science and Art, Department of Chemistry, Istanbul, 34220 Turkey \\ ${ }^{2}$ Istanbul Technical University, Faculty of Science and Art, Department of Chemistry, \\ İstanbul, 34467 Turkey \\ mozgur@yildiz.edu.tr
}

\begin{abstract}
A simple, rapid, and sensitive spectrophotometric method was developed for the simultaneous determination of butylated hydroxyanisole (BHA) and butylated hydroxytoluene (BHT) concentration in pharmaceutical preparations and chewing gums, without prior separation steps, using the H-point standard addition method (HPSAM).The concentration of one antioxidant was calculated by overlapping spectra at two appropriately selected wavelengths at which the interferent, other antioxidant, should has the same absorbance value. Absorbances at two pairs of wavelengths, 265 and $288 \mathrm{~nm}$ (with BHA as analyte) or 288 and $293 \mathrm{~nm}$ (with BHT as analyte) were monitored, while adding standard solutions of BHA or BHT, respectively. Calibration graphs were determined at $4-20 \mu \mathrm{gml}^{-1}(r=0.9981)$ for BHA and 20-100 $\mathrm{Mgml}^{-1}(r=0.9940)$ for BHT in binary mixtures. The proposed method was tested and validated using various parameters according to ICH guidelines. The limit of detection (LOD) and limit of quantification (LOQ) were found to be 0.48 and $1.51 \mu \mathrm{gml}^{-1}$ for BHA and 0.72 and $2.41 \mu \mathrm{gml}^{-1}$ for BHT, respectively. The percentage recovery ranges were $100.44-102.50 \%$ for BHA and $96.45-100.04 \%$ for BHT, with relative standard deviations (RSD) less than $1.48 \%$ indicating reasonable repeatability of the method. The intra-day and inter-day precision tests showed reliable RSD values $(<2 \%)$. The results obtained using HPSAM were statistically compared with results obtained using the derivative spectrophotometric method that was previously reported by us, showing high similarity between results.
\end{abstract}

Keywords: H-point standard addition method; phenolic antioxidants; spectrophotometry; butylated hydroxyanisole; butylated hydroxytoluene; pharmaceutical preparations; chewing gums

\section{ИСТОВРЕМЕНО СПЕКТРОФОТОМЕТРИСКО ОПРЕДЕЛВУАЊЕ НА КОНЦЕНТРАЦИИ НА ФЕНОЛНИ АНТИОКСИДАТОРИ (ВНА И ВНТ) ВО ФАРМАЦЕВТСКИ ПРЕПАРАТИ И ВО ГУМИ ЗА ЏВАКАЊЕ СО МЕТОД НА СТАНДАРДЕН ДОДАТОК СО Н-ТОЧКА}

\footnotetext{
Развиен е еден едноставен, брз и чувствителен спектрофотометриски метод за истовремено определување на концентрациите на бутилиран хидроксианизол (ВНА) и бутилиран хидрокситолуен (ВНТ) во фармацевтски препарати и во гуми за џвакање, без претходна сепарација, со употреба на метод на стандарден додаток со Н-точка (HPSAM). Концентрацијата на едниот од антиоксидаторите беше пресметана со препокривање на спектрите на две соодветно одбрани бранови должини, на кои интерферентната супстанца, другиот антиоксидатор, би требало да имаат иста вредност на апсорбанцата. Апсорбанците на двата пара бранови должини, 265 и 288 (за ВНА како аналит) или 288 и 293 (за ВНТ како аналит) се следени, при додавање на стандардни раствори соодветно на ВНА или ВНТ. Калибрационите криви соодветно се определени во опсегот од 4 до $20 \mu \mathrm{gml}^{-1}(r=0,9981)$ за ВНА и 20-100 $\mathrm{ggm}^{-1}(r=0,9940)$ за ВНТ. Предложениот метод е тестиран и валидиран со примена на разни параметри според упатствата на ICH. Прагот на
} 
детекција (LOD) и прагот на квантификација (LOQ) изнесуваа соодветно 0,48 и $1,51 \mu \mathrm{gml}^{-1}$ за BHA и 0,72 и $2,41 \mu \mathrm{gml}^{-1}$ за ВНТ. Аналитичките приноси соодветно изнесуваа $100,44-102,50 \%$ за ВНА и 96,45 - 100,04 \% за ВНТ со релативни стандардни девијации (RSD) помали од 1,48 \%, што укажува на добра повторливост на методот. Тестовите на дневната и меѓудневната прецизност покажуваат вредности на RSD < 2 \%. Резултатите со употреба на HPSAM беа статистички споредени со резултатите добиени со употреба на деривативен спектрофотометриски метод што претходно го имаме објавено и покажуваат сличност на добиените резултати.

Клучни зборови: статистички метод на Н-точка; фенолни антиоксидатори; спектрофотометрија; бутилиран хидроксианизол; бутилиран хидрокситолуен; фармацевтски препарати;

гуми за џвакање

\section{INTRODUCTION}

There is considerable current interest in antioxidants in food. Not only do they play a major role in determining the quality of food products, but they also participate in important biological processes that enhance health [1]. They are found either naturally or as additives in a large number of foods, pharmaceuticals, cosmetics, and other commercial products, where they prevent degenerative changes resulting from lipid oxidation. Many manufacturers prefer to use synthetic antioxidants because they are cheap and easily available. At present, synthetic antioxidants are used as food additives, but because of their possible toxicity, most countries have regulations in place to control their use in food production. Among the synthetic antioxidants, BHA and BHT are most commonly used in Turkey. The structures, E numbers and names of the antioxidants used in this study are shown in Figure 1. From previous studies, BHA and BHT are suspected to cause liver damage and carcinogenesis [2,3]. To ensure food safety and safeguard the health of the general public, the use of antioxidants in food is strictly controlled in many countries. Whether they are used singly, which is the usual case, or in combination, the permitted levels range from 100 to $200 \mathrm{mgkg}^{-1}$ [4].

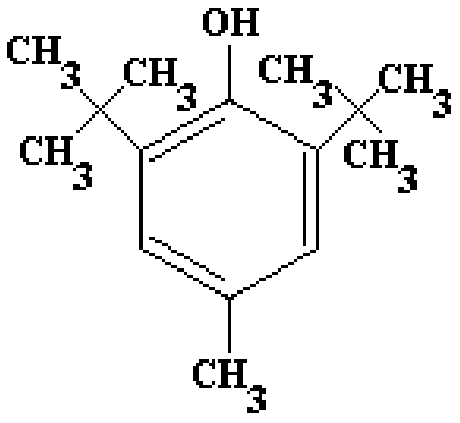

(E 321), butylated hydroxytoluene (BHT)
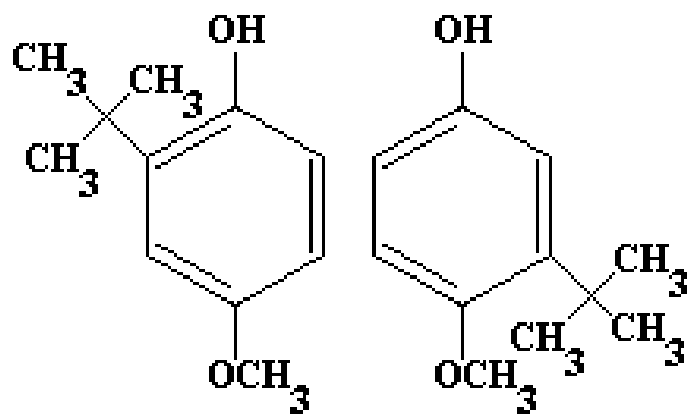

(E 320), butylated hydroxyanisole (BHA)

Fig. 1. The chemical structures, E numbers (numbers for synthetic food antioxidants in the international system of food additives), and common names of the antioxidants in this study.

The use of these additives is subject to regulations that define the permitted compounds and their concentration limits. As a consequence, there is a need for the analytical control of products that are prone to oxidation to verify the absence of prohibited antioxidants and presence of permitted antioxidants. In practice, it is more effective to use a mixture of two or more antioxidants rather than a single compound. Since these substances are chemically similar, they are difficult to analyze at trace levels without prior separation. Separation of antioxidants from matrix compounds by solvent extraction may result in a considerable amount of co-extraction and make subsequent purification necessary. In addition, this technique is labour intensive and time consuming, and uses large volumes of toxic organic solvents. In the literature, several analytical methods have been proposed for the determination of synthetic antioxidants, including high performance liquid chromatography (HPLC) [5-7], liquid chromatography-mass spectrometry (LC-MS ) [8, 9], gas chromatography-mass spectrometry (GC-MS) [10-12], micellar electrokinetic capillery chroma- 
tography (MECC) [13, 14], Fourier transform infrared spectroscopy (FTIR) [15], and electroanalysis [16]. Few UV-Vis spectrophotometric techniques have been developed for the simultaneous determination of BHA and BHT in samples [17, 18]. However, UV-Vis spectrophotometry, one of the most widely used analytical methods, is attractive due to its speed, simplicity, and broad application.

In 1988, Bosch-Reig and Campins-Falco $[19,20]$ developed the H-point standard addition method (HPSAM) that was based on the principle of dual wavelength spectrophotometry and standard addition methods. HPSAM can resolve spectra of two analytes with strongly overlapping spectra. This method also uses multicomponent analysis (the mathematical details of which have been described elsewhere [21-23]). Vardu-Andres et al. [24] and Campins-Falco et al. [25] have extended the HPSAM to resolve ternary mixtures.

In the proposed HPSAM method, two standard addition curves at two selected wavelengths are constructed. The standard addition method re- moves the matrix effects in samples without eliminating constant spectral interference. HPSAM transforms the incorrigible error to a constant systematic error, which can then be estimated and corrected. Previous studies highlight the high versatility and applicability of the method [26-34]. In this study, a detailed attempt has been made to simultaneously determine BHA and BHT using HPSAM in a simple, sensitive, and highly selective manner. BHA and BHT were analysed in a synthetic mixture and several different commercial products for method validation.

\subsection{Theoretical background of HPSAM}

Consider an unknown sample containing an analyte $(\mathrm{X})$ and an interferent $(\mathrm{Y})$. In this study, BHA and BHT were considered the analyte and interferent, respectively. Determining the concentration of $\mathrm{X}$ by HPSAM under this condition requires the selection of two wavelengths, $\lambda_{1}$ and $\lambda_{2}$, at which the interferent, $Y$, has the same absorbance value (Fig. 2) [35, 36].
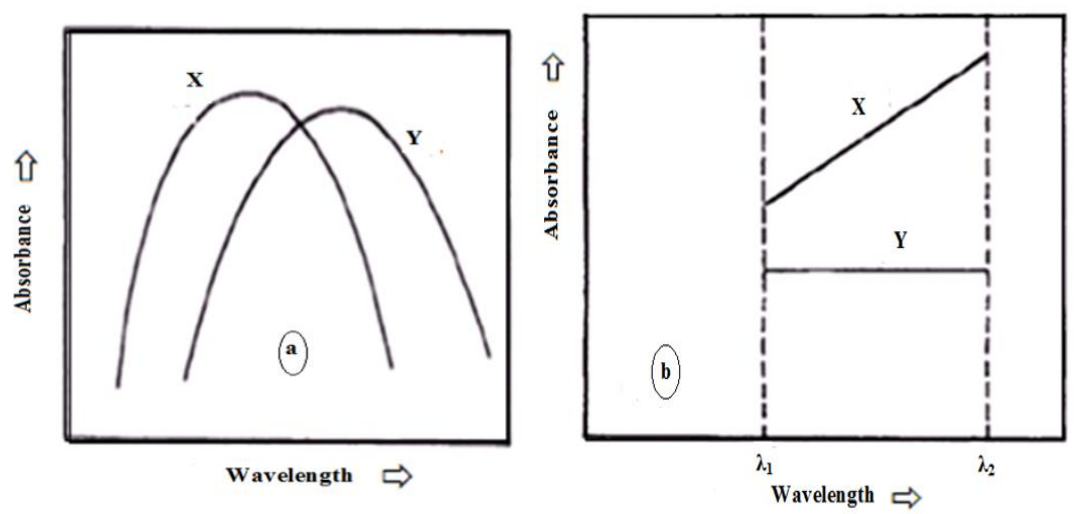

Fig. 2. (a). Absorption spectra of two compounds, where $\mathrm{X}$ is the analyte and $\mathrm{Y}$ is the interferent and (b) Required shape of the analyte $(\mathrm{X})$ and interferent $(\mathrm{Y})$ spectra in the wavelength interval $\lambda_{1}-\lambda_{2}$.

Known amounts of analyte (X) are successively added to the binary mixture of BHA and BHT solution and the resulting absorbances are measured at the two selected wavelengths. The absorbances can be expressed by the following equations:

$$
\begin{aligned}
& A_{(\lambda 1)}=\mathrm{b}_{0}+\mathrm{b}+\mathrm{M}_{\lambda 1} C_{\mathrm{i}} \\
& A_{(\lambda 2)}=A_{0}+A+\mathrm{M}_{\lambda 2} C_{\mathrm{i}}
\end{aligned}
$$

where $A_{\left(\lambda_{1}\right)}$ and $A_{\left(\lambda_{2}\right)}$ are the analytical signals measured at $\lambda_{1}$ and $\lambda_{2}$, respectively; $\mathrm{b}_{0}$ and $A_{0}$ $\left(\mathrm{b}_{0} \neq A_{0}\right)$ are the original analytical signals of $\mathrm{X}$ (in the sample) at $A_{(\lambda 1)}$ and $A_{(\lambda 2)} ; \mathrm{b}$ and $A$ are the analytical signals of Y (in the sample) at $A_{(\lambda 1)}$ and
$A_{(\lambda 2)} ; \mathrm{M}_{\lambda 1}$ and $\mathrm{M}_{\lambda_{2}}$ are the slopes of the standard addition calibration graphs at $\lambda_{1}$ and $\lambda_{2} ; C_{\mathrm{i}}$ is the concentration of added analyte $(\mathrm{X})$. By plotting the analytical signal against the concentration of added analyte, two straight lines are observed that intersect at the so-called H-point $\left(-\mathrm{C}_{\mathrm{H}}, \mathrm{A}_{\mathrm{H}}\right)$ (Fig. 3).

At the H-point, $A_{(\lambda 1)}=A_{(\lambda 2)}$ and $C_{\mathrm{i}}=C_{\mathrm{H}}$, and equations 3 and 4 can be expressed as follows:

$$
\begin{aligned}
& \mathrm{b}_{0}+\mathrm{b}+\mathrm{M}_{\lambda 1}\left(-\mathrm{C}_{\mathrm{H}}\right)=A_{0}+A+\mathrm{M}_{\lambda 2}\left(-C_{\mathrm{H}}\right) \\
& -C_{\mathrm{H}}=\left[\left(A_{0}-\mathrm{b}_{0}\right)+(A-\mathrm{b})\right] /\left(\mathrm{M}_{\lambda_{1}}-\mathrm{M}_{\lambda 2}\right)
\end{aligned}
$$

From equation 4 , the following conclusions can be obtained: 
$\mathrm{Y}$ is the known interferent and the analytical signal corresponding to $\mathrm{Y}$,

b (at $\lambda_{1}$ or $\lambda_{2}$ ) does not change with the additions of analyte $\mathrm{X}$,

then $\mathrm{b}=A=$ constant, and:

$-C_{\mathrm{H}}=\left(A_{0}-\mathrm{b}_{0}\right) /\left(\mathrm{M}_{\lambda 1}-\mathrm{M}_{\lambda 2}\right)=-\mathrm{b}_{0} / \mathrm{M}_{\lambda 1}=-A_{0} / \mathrm{M}_{\lambda 2}$

where $C_{\mathrm{H}}=C_{\mathrm{X}}$ and $C_{\mathrm{X}}$ corresponds to the analyte concentration in the mixture, as $-C_{\mathrm{H}}$ depends only on variables related to the analyte [37].

If the value of $-C_{\mathrm{H}}$ is included in equation 1 , $A_{\mathrm{H}}$, the ordinate value of the point of intersection can be described as follows:

$$
\begin{aligned}
A_{\mathrm{H}} & =\mathrm{b}_{0}+\mathrm{b}+\mathrm{M}_{\lambda 1}\left(-C_{\mathrm{H}}\right) \\
\mathrm{b}_{0}=\mathrm{M}_{\lambda 1} C_{\mathrm{H}}, A_{\mathrm{H}} & =\mathrm{b} \text { and similarly, }
\end{aligned}
$$

$$
A_{\mathrm{H}}=A
$$

Therefore $\mathrm{Y}$ can be quantified by considering $A_{\mathrm{H}}=A_{\mathrm{Y}}$ and running a calibration graph at $\lambda_{1}$ (or $\lambda_{2}$ ) for pure Y. According to the above discussion about the H-point, $C_{\mathrm{H}}$ is independent of the concentration of the interferent in equation 4 , and therefore, $A_{\mathrm{H}}$ is also independent of the analyte concentration in equations 5 and 6 . The main difference between the HPSAM and the standard addition method is that the coordinate of the H-point $\left(A_{\mathrm{H}}\right)$, i.e. that which provides the concentration of $\mathrm{X}\left(-C_{\mathrm{H}}\right)$, is non-zero as $\lambda_{1}$ and $\lambda_{2}$ are chosen to obtain identical absorbance values for $\mathrm{Y}(\mathrm{b}=A \neq 0)[18]$. Hence, the value of $A_{\mathrm{H}}$ is only related to the signal of interferent $\mathrm{Y}$ at the two selected wavelengths. To evaluate the interferent concentration from the ordinate value of the $\mathrm{H}$ point $\left(A_{\mathrm{H}}\right)$, a calibration curve of the absorbance value of a standard interferent is needed. Similarly, to determine $\mathrm{Y}$ by HPSAM under these conditions, two wavelengths $\lambda_{1}$ and $\lambda_{2}$ must be selected at which the species $X$ can have the same absorbance.

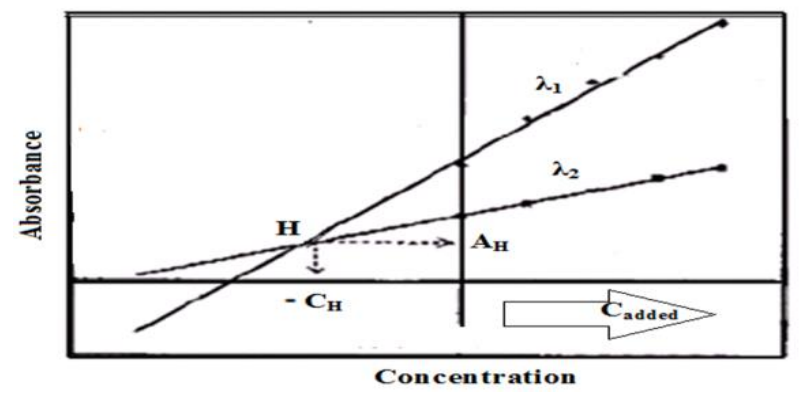

Fig. 3. Plot of the H-point standard additions method. $C_{\text {added }}$ is the added analyte concentration. $\mathrm{H}$ is the H-point, $\lambda_{1}$ and $\lambda_{2}$ are the selection wavelengths, $-C_{H}$ is the analyte concentration and $A_{\mathrm{H}}$ is the analytical signal of the interferent at H-point.

\section{EXPERIMENTAL}

\subsection{Apparatus}

All spectral measurements were carried out on a double beam Shimadzu UV-Vis 1800 spectrophotometer (Tokyo, Japan) with two matched $1 \mathrm{~cm}$ quartz cells, connected to an HP-PC computer and an HP 1320 laser printer. Bundled UV-PC personal spectroscopy software, UV-probe version 2.21, was used to process absorption and derivative spectra. All spectra were recorded over the range 200-320 nm with a $1 \mathrm{~nm}$ slit width. A Hettich EBA 20 centrifuge and $0.45 \mu \mathrm{m}$ membrane filters (Sartorius, Goettingen, Germany) were used in this study. An ultrasonic water bath (Intersonik, Turkey) and magnetic stirrer (Heidolph MR Hei Standard, Germany) were used to extract BHA and BHT.

\subsection{Chemicals and materials}

All chemicals used were of analytical grade. BHA (E 320) and BHT (E 321) were obtained from Sigma (St. Louis, MO, USA). Chewing gum samples were purchased from local markets and pharmaceutical preparations were from local pharmacies. Spectrophotometric-grade methanol was purchased from Merck (Darmstadt, Germany).

\subsubsection{Commercial chewinggum samples}

Falım (mastic-flavored sugar-free gum) is produced by the Kent Food Company, Turkey. The batch number of the sample used was L0706234. The gum contains gum base, flavorings, colorant (E171), and antioxidants (E320 and E321).

Vivident Xylit is produced by the Perfetti Van Melle Food Company, Kocaeli, Turkey. It contains $66 \%$ sweeteners (sorbitol, xylitol, maltitol and aspartame), $1.6 \%$ natural flavorings, gum base, $0.9 \%$ flavorings that are identical to natural flavorings, thickener(gumarabic), stabilizer (glycerol), emulsifier (soylecithin), polisher (E903), colorant (E171), and antioxidant (BHA). The batch number of the sample used was E:12/2014.

First (mastic-flavored sugar-free gum) is also produced by the Kent Food Company, Turkey. The batch number of the sample used was L0503236. It contains sweeteners (sorbitol, xylitol, maltitol, mannitol, aspartame and acesulfameK), flavorings, gumbase, thickener (E414), stabilizer (glycerol), emulsifier (sunflower lecithin), polisher (E903), colorant (E171), and antioxidant (BHT). 


\subsubsection{Pharmaceutical formulations}

Devit 3-Oral Drops each $15 \mathrm{ml}$ contains 50000 IU vitamin D3, antioxidant (BHA) and sunflower oil. It is manufactured by Deva A.Ş, Istanbul, Turkey. The batch number was A023705.

Metrin Skin Cream (5\% w/w) contains $50 \mathrm{mg}$ permethrin, $6.6666 \%$ cetylalcohol, $2 \%$ emulgent 5 $\%$ liquid paraffin, $6.6666 \%$ propylene glycol, $0.1 \%$ nipagin, $0.05 \%$ nipasol, $0.01 \%$ citric acid, $0.02 \%$ BHT, and deionized water. It is manufactured by the Bikar Pharm Company, Istanbul, Turkey. The batch number used was 2013-03.

\subsection{Stock and standard solutions}

Stock solutions of BHA $\left(200 \mu \mathrm{gml}^{-1}\right)$ and BHT $\left(500 \mu \mathrm{gml}^{-1}\right)$ were prepared in methanol. These solutions were stored in glass-stopped bottles in the dark at $4{ }^{\circ} \mathrm{C}$. Standard and working solutions were prepared daily by diluting appropriate amounts of the stock solutions with methanol. BHA and BHT stock solutions were diluted to obtain standard solutions at concentrations range of 4-20 $\mu \mathrm{gl}^{-1}$ and $20-100 \mu \mathrm{gml}^{-1}$, respectively.

\subsection{Procedures}

\subsubsection{Construction of calibration curves}

Calibration curves were calculated for each antioxidant separately in the presence of a fixed amount of the other antioxidant. BHA and BHT were simultaneously determined using HPSAM by measuring the absorbance values at $265 \mathrm{~nm}$ and $288 \mathrm{~nm}$ (when standard solutions of BHA were added) and plotted to ascertain the concentration of BHT. Two straight lines for the absorbance and concentration were plotted and the values at the intersection of these lines (H-point), termed $\mathrm{C}_{\mathrm{H}}$ and $\mathrm{A}_{\mathrm{H}}$, respectively, were obtained by extrapolation. For the construction of the BHA calibration graph, absorbance values were measured at $288 \mathrm{~nm}$ and $293 \mathrm{~nm}$ (when standard BHT solutions were added) and the H-point graphs were obtained.

\subsubsection{Analysis of BHA and BHT in laboratory prepared mixtures}

For validation, five synthetic mixtures of BHA and BHT containing different concentration ratios (varying from 1:1.25 to $1: 25$ ) were prepared, and standard additions of BHA (up to $20 \mu \mathrm{gml}^{-1}$ ) or BHT (up to $100 \mu \mathrm{gml}^{-1}$ ) were made. The concentrations of BHA and BHT were calculated this method.

\subsubsection{Preparation of real samples}

\subsubsection{Treatment of chewinggum samples}

Three commercial chewing gum samples (CG1, CG2 and CG3) were analyzed. CG1 contained BHA and BHT, CG2 contained BHA, and CG3 contained BHT. The chewing gum sample (12 g) was accurately weighed, finely chopped and dissolved in $80 \mathrm{ml}$ methanol. The mixture was then added to an ultrasonic water bath for $20 \mathrm{~min}$. The solution was filtered and transferred quantitatively into a $100 \mathrm{ml}$ volumetric flask. Methanol was then added to the flask to $100 \mathrm{ml}$.The relevant dilutions were made to obtain the concentrations within the linearity range of calibration curves. The concentrations of BHA and BHT were calculated using this method.

\subsubsection{Treatment of pharmaceutical preparations}

Two pharmaceutical preparations ( $\mathrm{P} 1$ and $\mathrm{P} 2$ ) were analyzed. $\mathrm{P} 1$ contained BHA and $\mathrm{P} 2$ contained BHT. The P1 sample $(10 \mathrm{ml})$ was placed in a $100 \mathrm{ml}$ erlenmeyer flask and $50 \mathrm{ml}$ methanol was added. The mixture was stirred magnetically for 30 min and the methanol phase was removed. The appropriate volume of sample was transferred to a $10 \mathrm{ml}$ volumetric flask and diluted to $10 \mathrm{ml}$ with methanol.

The $\mathrm{P} 2$ sample $(15 \mathrm{~g}$ ) was placed in a $50 \mathrm{ml}$ erlenmeyer flask and $30 \mathrm{ml}$ methanol was added. The mixture was stirred magnetically for $30 \mathrm{~min}$ and the solution was centrifuged. The upper phase was removed. The appropriate volume of sample was transferred to a $10 \mathrm{ml}$ volumetric flasks and diluted to $10 \mathrm{ml}$ with methanol. The samples were stored in darkness at $4{ }^{\circ} \mathrm{C}$ until analysis. The procedure described in section 2.4.1 was used to analyze the antioxidants in these solutions. The absorption spectra of these solutions were recorded in the wavelength range of $200-320 \mathrm{~nm}$ with methanol as a blank. The concentrations of each antioxidant in the synthetic mixtures and samples were then calculated.

\section{RESULTS AND DISCUSSION}

A simple, one-step spectrophotometric method was developed for the simultaneous determination of BHA and BHT in binary mixtures with overlapping spectra. The absorption spectra of BHA, BHT, and a binary mixture are shown in Figures 4 and 5. As shown in Figures 4 and 5, the maximum wavelengths of both compounds are 
close to each other and their spectra overlap. Therefore, BHT cannot be determined by directly measuring its absorbance in the presence of BHA. BHA can be approximately determined by directly measuring its absorbance if there is no matrix effect. Thus, determination of BHA and BHT in a binary mixture is impossible using classical spectrophotometry. However, after application of HPSAM, accurate and simple simultaneous determination of BHA and BHT can be achieved. This method allows the determination of two species with extensively overlapped spectra.

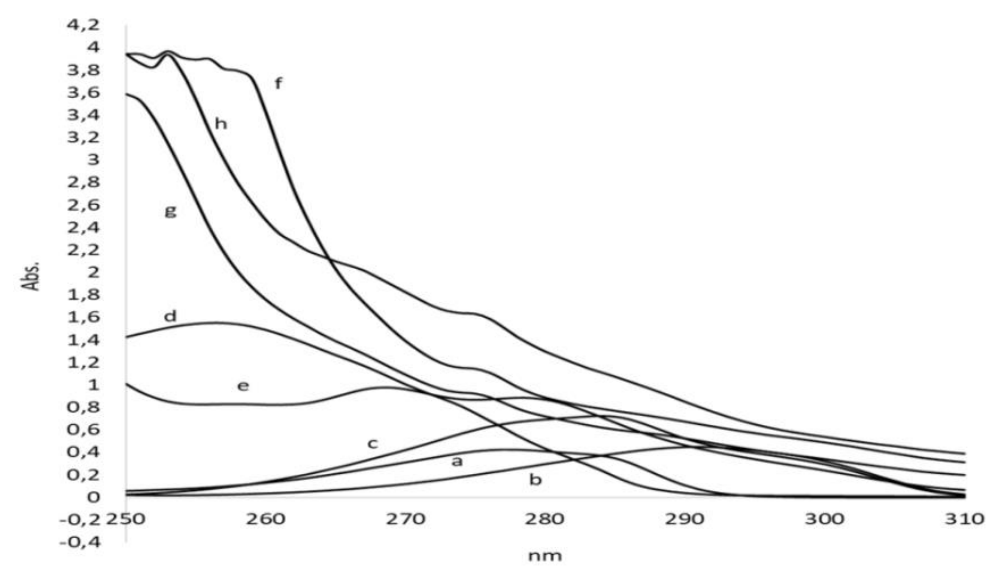

Fig. 4. Absorption spectra of (a) $50 \mu \mathrm{gml}^{-1} \mathrm{BHT}$, (b) $20 \mu \mathrm{gml}^{-1} \mathrm{BHA}$, (c) $20 \mu \mathrm{gml}^{-1} \mathrm{BHA}$ and $50 \mu \mathrm{gml}^{-1} \mathrm{BHT}$, (d) P2, (e) P1, (f) CG2, (g) CG3, (h) CG1

To use HPSAM, analytical signal data at two selected wavelengths are required. At these selected wavelengths the following must be true: the analyte signals must be linear to the concentration; the interferent signals must remain equal, even if the analytical concentrations are changed; and the analytical signals of the analyte and interferent mixture should be equal to the sum of the individual signals of the two compounds. In addition, the slope difference of the two straight lines obtained at $\lambda_{1}$ (or $\lambda_{3}$ ) and $\lambda_{2}$ (or $\lambda_{4}$ ) must be as large as possible for higher accuracy and sensitivity [38-40].

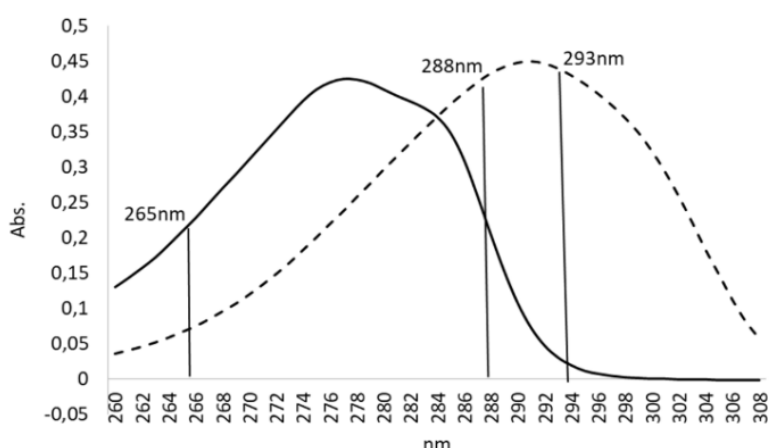

Fig. 5. Absorption spectra of $20 \mu \mathrm{gml}^{-1} \mathrm{BHA}(--)$ and $50 \mathrm{\mu gml}^{-1}$ BHT (-) using methanol as a blank with the selected wavelengths for HPSAM.

In this study, either BHA or BHT can be considered as the analyte and the other as the interferent.The determination of BHA and BHT was carried out using HPSAM. Several pairs of wavelengths could have been selected from the BHA and BHT spectra. As observed in Figure 5 of the most favorable pairs of analytical wavelengths are $288 \mathrm{~nm}$ and $293 \mathrm{~nm}$, and $265 \mathrm{~nm}$ and $288 \mathrm{~nm}$, respectively. At these selected wavelengths, BHT signals increases linearly with the increase in BHT concentration, and the BHA signals do not change. At these wavelengths, maximum sensitivity differences are attainable. A linear correlation was observed at $4-20 \mu \mathrm{gml}^{-1}$ and at $265 \mathrm{~nm}$ and $288 \mathrm{~nm}$ wavelengths for BHA, and at $288 \mathrm{~nm}$ and $293 \mathrm{~nm}$ wavelengths and $20-100 \mu \mathrm{gml}^{-1}$ for BHT (Table 1). The appropriate correlation coefficients obtained (0.9981 for BHA and 0.9940 for BHT) indicate that interaction between the two antioxidants does not exist. The concentration of the interferent was calculated in each test solution using the calibration method with a single standard and the ordinate value of the H-point $\left(A_{\mathrm{H}}\right)$. Plotting the analytical signal against added analyte concentration produced two straight lines (Figure 6) that intersected at coordinates $\mathrm{H}\left(-C_{\mathrm{H}}, A_{\mathrm{H}}\right)$, where $-C_{\mathrm{H}}$ is the unknown analyte (BHA) concentration and $\mathrm{A}_{\mathrm{H}}$ the analytical signal of the interferent (BHT). Figure 7 shows the plot obtained at selected wavelengths on adding standard solutions of BHT, where $-C_{\mathrm{H}}$ is the unknown analyte (BHT) concentration and $\mathrm{A}_{H}$ the analytical signal due to the interferent (BHA). As expected in HPSAM, at the H-point, $C_{\mathrm{H}}$ is independent of interferent concentration, and $A_{\mathrm{H}}$ is dependent on the interferent. 
T a ble 1

Assay validation sheet of the proposed method for the determination of BHA and BHT

\begin{tabular}{|c|c|c|}
\hline Parameters & BHA & BHT \\
\hline \multicolumn{3}{|l|}{ Accuracy $(\text { mean } \pm \mathrm{SD})^{\mathrm{x}}$} \\
\hline Specificity & $101.43 \pm 0.69$ & $99.16 \pm 1.39$ \\
\hline \multicolumn{3}{|l|}{ Precision (RSD \%) } \\
\hline Repeatability* & 1.18 & 1.22 \\
\hline Intermediate precision ${ }^{* *}$ & 1.09 & 1.34 \\
\hline Concentration range & $4-20 \mu \mathrm{gml}^{-1}$ & $20-100 \mu \mathrm{gml}^{-1}$ \\
\hline Wavelengths pairs(nm) & $265 ; 288$ & $288 ; 293$ \\
\hline Slope & 0.021 & 0.004 \\
\hline Intercept & 0.580 & 0.402 \\
\hline Correlation coefficient $(r)$ & 0.9981 & 0.9940 \\
\hline Limit of detection (LOD), $\mu \mathrm{gml}^{-1}$ & 0.48 & 0.72 \\
\hline Limit of quantitation (LOQ) $\mu \mathrm{gml}^{-1}$ & 1.51 & 2.41 \\
\hline
\end{tabular}

*:The intra-day $(n=10)$ average of three concentrations $\left(4,12\right.$ and $\left.20 \mu \mathrm{gml}^{-1}\right)$ for BHA and $\left(20,60\right.$ and $\left.100 \mu \mathrm{gml}^{-1}\right)$ for BHT repeated three times per day.

$* *$ :The inter-day $(n=10)$ average of three concentrations $\left(4,12\right.$ and $\left.20 \mu \mathrm{gml}^{-1}\right)$ for BHA and $\left(20,60\right.$ and $\left.100 \mu \mathrm{gml}^{-1}\right)$ for BHT repeated three times over three consecutive days. ${ }^{x}$ mean $\pm \mathrm{SD}(n=10)$

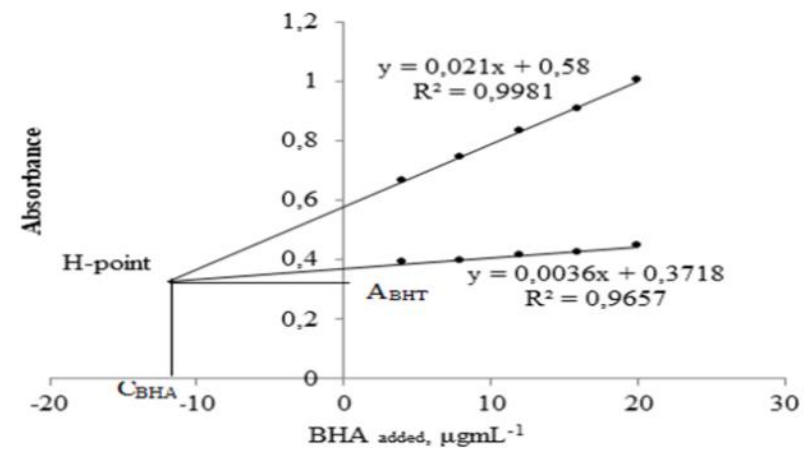

Fig. 6. H-point standard addition plot for the simultaneous determination of BHA and BHT with a constant concentration of BHA $\left(12 \mu \mathrm{gml}^{-1}\right)$ and BHT $\left(80 \mu \mathrm{gml}^{-1}\right)$ and different BHA concentrations $\left(4-20 \mu \mathrm{gml}^{-1}\right)$.

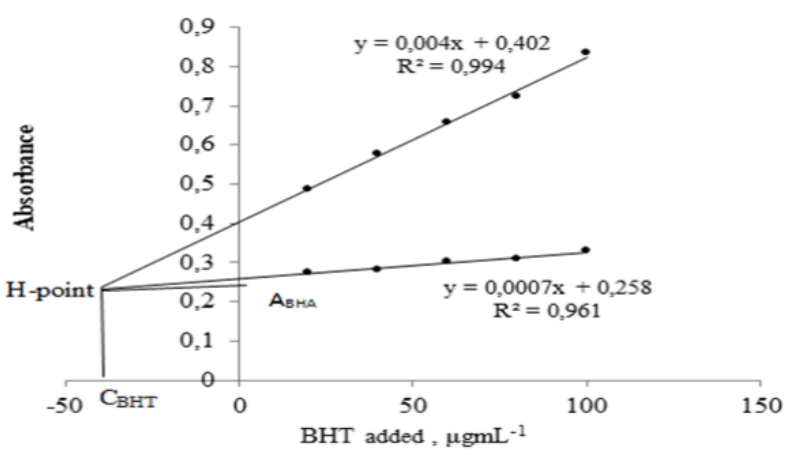

Fig. 7. H-point standard addition plot for the simultaneous determination of BHA and BHT with a constant concentration of BHT $\left(40 \mu \mathrm{gml}^{-1}\right)$ and BHA $\left(12 \mu \mathrm{gml}^{-1}\right)$ and different BHT concentrations $\left(20-100 \mu \mathrm{gml}^{-1}\right)$.

\subsection{Method validation}

The method was validated for the following parameters: linearity, LOQ, LOD, precision, and accuracy. Analytical procedures was also validated according to the International Conference on Harmonization Q2B guidelines [41-43] to determine the linearity, sensitivity, precision, and accuracy for each analyte [44-46].

\subsection{1. $L O D$ and $L O Q$}

In this study, the LOD and LOQ were based on the standard deviation of response and the slope of the corresponding curve using the following equations:

$$
\begin{aligned}
\mathrm{LOD} & =3 \mathrm{~S} / \mathrm{m} \\
\mathrm{LOQ} & =10 \mathrm{~S} / \mathrm{m}
\end{aligned}
$$

where $S$, the noise estimate, is the standard deviation of the absorbance of the sample, and $m$ is the slope of the relevant calibration graphs. LOD is the signal corresponding to the detection limit and LOQ is defined as the lowest concentration of the standard curve that can be measured with acceptable accuracy, precision, and variability [47]. The LOD and LOQ were 0.48 and $1.51 \mu \mathrm{gml}^{-1}$ for

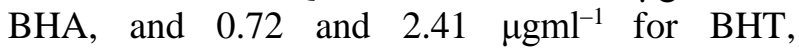
respectively (Table 1). The validation parameters according to the ICH guidance on accuracy, repeatability, and intermediate precision are also presented in Table 1. The low LOD and LOQ values 
are an advantage of this method and all statistical values were within the acceptable limits.

\subsubsection{Precision}

The precision of the method was determined by studying the repeatability (intra-day) and the intermediate precision (inter-day), and reported as relative standard deviation(RSD) for a statistically significant number of replicate measurements. Three different levels of antioxidant concentrations: lower concentration (LC), intermediate concentration (IC), and higher concentration (HC) were prepared three times a day and studied for intra-day variation. The three chosen concentrations to test the samples of BHA were 4, 12 and $20 \mathrm{\mu gml}^{-1}$, and for BHT were 20, 60 and 100 $\mu \mathrm{gml}^{-1}$. The RSD of the three assay values at three consecutive concentration levels was calculated. The same procedure was followed for three different days in order to study inter-day variation.
The calculated RSD values for both antioxidants were within the accepted limit (less than $2 \%$, Table 1). This shows that the proposed method has excellent repeatability and intermediate precision.

\subsubsection{Accuracy}

The accuracy of the method was assessed by determining recovery values. Ten replicate experiments of binary mixtures of BHA and BHT were carried out to assess the reproducibility of the results. BHA and BHT were determined simultaneously using the concentration ratios varying from 1:1.25 to $1: 25$ in mixed samples. The composition of the mixtures, the mean percentage recoveries, and standard deviations are given in Table 2. The high mean recovery values (96.45-102.50 \%), close to $100 \%$, and low standard deviations (SD $<1.4 \%$ ) represent show high accuracy.

\section{Table 2}

Accuracy of the method for simultaneous determination of BHA and BHT in the different binary mixtures

\begin{tabular}{cccccc}
\hline \hline \multicolumn{2}{c}{ Sample $\left(\mu \mathrm{gml}^{-1}\right)$} & \multicolumn{2}{c}{ Found $\left(\mu \mathrm{gml}^{-1}\right)^{*}$} & \multicolumn{2}{c}{ Recovery $(\%)$} \\
\hline BHA & BHT & BHA & BHT & BHA & BHT \\
\hline 4 & 100 & $4.04 \pm 0.04$ & $99.74 \pm 0.06$ & 101.00 & 99.74 \\
8 & 60 & $8.12 \pm 0.03$ & $59.60 \pm 0.03$ & 101.50 & 99.33 \\
12 & 40 & $12.30 \pm 0.06$ & $40.09 \pm 0.04$ & 102.50 & 100.22 \\
16 & 20 & $16.07 \pm 0.02$ & $19.29 \pm 0.07$ & 100.44 & 96.45 \\
20 & 80 & $20.34 \pm 0.04$ & $80.03 \pm 0.02$ & 101.70 & 100.04 \\
Mean & & & & 101.43 & 99.16 \\
SD & & & & 0.69 & 1.39 \\
RSD $(\%)$ & & & & 0.68 & 1.40 \\
\hline \hline
\end{tabular}

$*$ mean \pm SD $(\mathrm{n}=10)$

Different calibrations were plotted for various synthetic mixtures, with differing BHA and BHT concentrations, to assess the accuracy and specificity of the two selected pairs of wavelengths for antioxidant determination for the use of HPSAM for the determination of BHT and BHA was evaluated using a series of samples containing fixed amounts of BHA with differing amounts of BHT (Fig. 7) or fixed amounts of BHT with differing amounts of BHA (Fig. 8). At the H-point, $C_{\mathrm{H}}$ (concentration of BHA at H-point) is independent of BHT concentration and, therefore, $A_{\mathrm{H}}$ (absorbance signal at H-point) is also independent of BHA concentration. Figures 8 and 9 clearly show the effect of change in concentration of BHA and BHT on the position of the $\mathrm{H}$-point, respectively. As shown in Figures 9 and 10, the value of $A_{H}$ is independent of the amounts of BHA in the samples. This analytical signal enables the calculation of BHT concentration from a calibration curve constructed using the ordinate values of several HPSAM plots with varying concentrations of BHT. The applicability of HPSAM in determining BHA and BHT in a series of samples containing a fixed amount of BHT with differing amounts of BHA (Fig. 10) or a fixed amount of BHA with differing amounts of BHT (Fig. 11) was assessed by adding standard solutions of BHT. As shown in Figures 8 and 11, the value of $A_{\mathrm{H}}$ is independent of the amounts of BHT in the samples. The results 
show that the concentrations of BHA and BHT in the samples were determined accurately, and the applicability of this method has been confirmed.

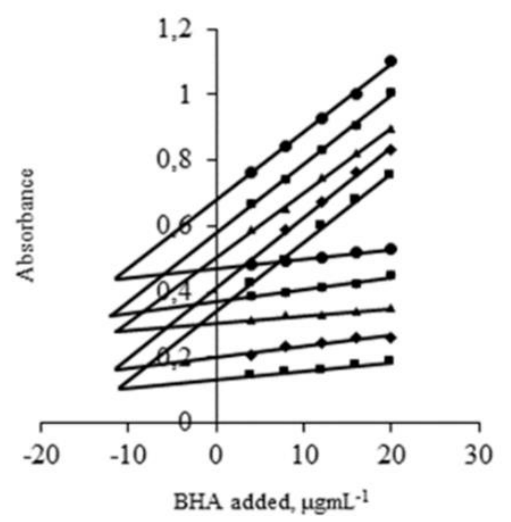

Fig. 8. H-point standard addition plot for a fixed BHA concentration $\left(12 \mu \mathrm{gml}^{-1}\right)$ and varying concentrations of BHT (20$100 \mu \mathrm{gml}^{-1}$ ) when different standard BHA solutions are added. - = BHT $20 \mu \mathrm{gml}^{-1} ; \bullet=$ BHT $40 \mu \mathrm{gml}^{-1} ; \boldsymbol{\Delta}=$ BHT $60 \mu \mathrm{gml}^{-1}$; $\bullet=$ BHT $80 \mu \mathrm{gml}^{-1} ; \bullet=$ BHT $100 \mu \mathrm{gml}^{-1}$

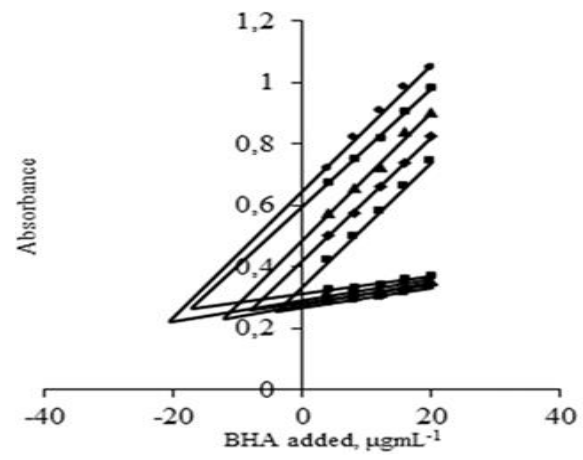

Fig. 9. H-point standard addition plot for varying BHA concentrations (4-20 $\left.\mu \mathrm{gml}^{-1}\right)$ and a fixed BHT concentration (60 $\mu \mathrm{gml}^{-1}$ ) when different standard BHA solutions are added. - = BHA $4 \mu \mathrm{gml}^{-1} ; \diamond=$ BHA $8 \mu \mathrm{gml}^{-1} ; \mathbf{\Delta}=$ BHA $12 \mu \mathrm{gml}^{-1}$; $\bullet=$ BHA $16 \mu \mathrm{gml}^{-1} ; \bullet=$ BHA $20 \mu \mathrm{gml}^{-1}$

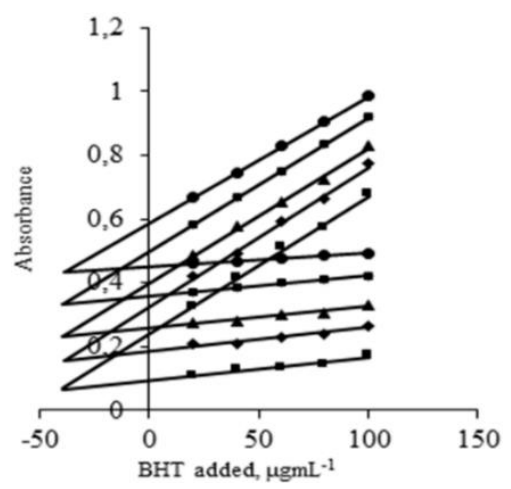

Fig. 10. H-point standard addition plot for a fixed BHT concentration $\left(40 \mu \mathrm{gml}^{-1}\right)$ and varying concentrations of BHA (4-

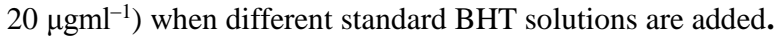
- = BHA $4 \mu \mathrm{gml}^{-1} ;=$ BHA $8 \mu \mathrm{gml}^{-1} ; \boldsymbol{\Delta}=$ BHA $12 \mu \mathrm{gml}^{-1}$; - = BHA $16 \mu \mathrm{gml}^{-1} ; \bullet=$ BHA $20 \mu \mathrm{gml}^{-1}$

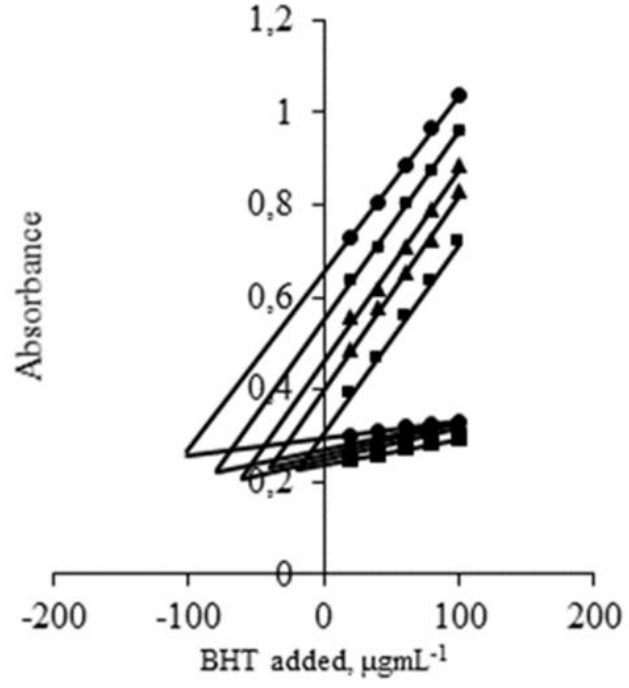

Fig. 11. H-point standard addition plot for varying BHT concentrations $\left(20-100 \mu \mathrm{gml}^{-1}\right)$ and a fixed BHA concentration $\left(12 \mu \mathrm{gml}^{-1}\right)$ when different standard BHT solutions are added. -BHT $=20 \mu \mathrm{gml}^{-1} ; \diamond \mathrm{BHT}=40 \mu \mathrm{gml}^{-1} ; \boldsymbol{\Delta}=$ BHT $60 \mu \mathrm{gml}^{-1}$; $\bullet=$ BHT $80 \mu \mathrm{gml}^{-1} ; \bullet=$ BHT $100 \mu \mathrm{gml}^{-1}$

\subsubsection{Stability}

Stock solutions of BHA and BHT were covered in aluminium foil, and showed no spectrophotometric changes for more than 2 weeks when stored in glass-stopped bottles in the dark at $4{ }^{\circ} \mathrm{C}$.

\subsection{Application of the method to real samples}

The proposed method was successful in determining the concentrations of BHA and BHT in several commercial products. Three chewing gums and two pharmaceuticals samples were purchased from the local supermarket and pharmacy in Istanbul, Turkey. The results are given in Table 3, and the absorption spectra of the samples are shown in Figure 4. The results indicate that this method is accurate and reliable for both antioxidants. The results were also statistically compared with results of the first derivative spectrophotometric method, previously reported by us [48], at $95 \%$ confidence level by student's $t$-test and the variance ratio $F$ test (Table 3). No significant difference was observed between the two methods at $P=0.05$ for commercial products. HPSAM has proved to be sensitive, accurate, and precise and should be applied to routine analysis of antioxidants. 
Table 3

Determination of BHA and BHT content in chewing gums and pharmaceutical preparations by HPSAM and a comparative method (the derivative spectrophotometric method)

\begin{tabular}{|c|c|c|c|}
\hline \multicolumn{2}{|c|}{ Assay results } & (mg antioxidant /100 g sample) & \multirow[b]{2}{*}{$\begin{array}{c}\text { First derivative spectrophotometric } \\
\text { method } \\
\text { (Comparison Method) } \\
(\text { mean } \pm \text { RSD })^{*}\end{array}$} \\
\hline Sample & Analyte & $\begin{array}{l}\text { H-Point standard method }(\text { mean } \pm \text { RSD } \%)^{*} \\
\left(\mathrm{t}_{\text {calculated }} ; \mathrm{F}_{\text {calculated }}\right) * *\end{array}$ & \\
\hline P1 & BHA & $18.26 \pm 1.14(1.17 ; 1.20)$ & $18.42 \pm 1.21$ \\
\hline $\mathrm{P} 2$ & BHT & $24.75 \pm 1.18(1.11 ; 1.07)$ & $24.55 \pm 1.15$ \\
\hline \multirow[t]{2}{*}{ CG1 } & BHA & $31.42 \pm 1.47(1.81 ; 1.00)$ & $30.87 \pm 1.61$ \\
\hline & BHT & $93.54 \pm 1.42(0.74 ; 1.11)$ & $94.18 \pm 1.49$ \\
\hline \multirow[t]{2}{*}{ CG2 } & BHA & $26.18 \pm 1.21(1.30 ; 1.51)$ & $25.94 \pm 1.25$ \\
\hline & BHT & $98.63 \pm 1.09(0.56 ; 1.15)$ & $98.23 \pm 1.18$ \\
\hline
\end{tabular}

*Results are the average of five experiments for both methods.

**The corresponding theoretical value for $t$ and $F$ at $P=0.05$ (t $\mathrm{t}_{\text {theoretical }}$ : $2.31 ; \mathrm{F}_{\text {theoretical }}$ : 6.39).

\section{CONCLUSION}

The suggested method shows that HPSAM is well adapted to resolve binary mixtures of BHA and $\mathrm{BHT}$, and is comparable to the derivative spectrophotometric method in the chewinggum samples and pharmaceutical preparations studied.The data show that the results obtained by HPSAM are accurate, precise and specific. The method is simple to apply with inexpensive instrumentation, and gives satisfactory quantitative results for complex products such as chewinggum, jelly capsules, and skin cream. The method was validated and should be used for regular quality control testing due to its simplicity and wide ranging applicability. The method also offers good selectivity, accuracy, and precision that can be applied to different concentration ratios.

\section{REFERENCES}

[1] L. Langseth, Oxidants, antioxidants, and disease prevention, The International Life Sciences Institute Press, Belgium, 1995.

[2] D. B. Clayson, F. Iverson, E. Nera, E. Lok, C. Rogers, C. Rodrigues, Histopathological and radioautographical studies on the forestomach of F344 rats treated with butylated hydroxyanisole and related chemicals, Food Chem. Toxicol., 24 (10-11), 1171-1182 (1986). DOI: 10.1016/0278-6915(86)90305-4.

[3] N. Ito, S. Fukushima, S. Tamano, S. M. Hirose, A. hagiwara, dose response in butylated hydroxyanisole induction of forestomach carcinogenesis in F344 rats, JNCI J. Natl. Cancer Inst., 77 (6), 1261-1265 (1986).

[4] D. L. Madhavi, S. S. Deshpande, D. K. Salunkhe, Food antioxidants: Toxicological aspects of food antioxidant, Marcel Dekker Inc, New York, USA, 1996.
[5] B. Saad, Y. Y. Sing, M. A. Nawi, N. H. Hashim, A. S. Mohamed Ali, M. I. Saleh, S. F. Sulaiman, K. M. Talib, K. Ahmad, Determination of synthetic phenolic antioxidants in food items using reversed-phaseHPLC, Food Chem., 105, 389-394 (2007). DOI: 10.1016/j.foodchem.2006.12.025.

[6] W. M. Della Sin, Y. C. Wong, C. Y. Mak, S. T. Sze, W. Y. Yao, Determination of five phenolic antioxidants in edible oils: Method validation and estimation of measurement uncertainty, J. Food Comp. Anal., 19, 784-791 (2006). DOI: 10.1016/j.jfca.2005.12.005.

[7] M. Chen, Q. Xia, M. Liu, Y. Yang, Cloud-point extraction and reversed-phase high performance liquid Chromatography for the Determination of Synthetic phenolic antioxidants in edible oils, J. Food Sci., 76 (1) 98-103 (2011). DOI: 10.1111/j.1750-3841.2010.01914.x.

[8] M. R. Lee, C. Y. Lin, Z. G. Li, T. F.Tsai, Simultaneous analysis of antioxidants and preservatives in cosmetics by supercritical fluid extraction combined with liquid chromatography-mass spectrometry, J. Chromatogr A, 1120, 244-251 (2006).

DOI: $10.1016 /$ j.chroma.2006.01.075.

[9] S. Tsuji, M. Nakanoi, H. Terada, Y. Tamura, Y. Tonogai, Determination and confirmation of five phenolic antioxidants in foods by LC/MS and GC/MS, Shokuhin Eiseigaku Zasshi, 46 (3) 63-71(2005).

DOI: 10.3358/shokueishi.46.63.

[10] L. Guo, M. Y. Xie, A. P. Yan, Y. Q. Wan, Y. M. Wu, Simultaneous determination of five synthetic antioxidants in edible vegetable oil by GC-MS, Anal. Bioanal. Chem., 386 (6) 1881-1887 (2006). DOI: $10.1007 / \mathrm{s} 00216-006-0738-1$.

[11] R. Rodil, J. B. Quintana, G. Basaglia, M. C. Pietrogrande, R. Cela, Determination of synthetic phenolic antioxidants and their metabolites in water samples by downscaled solid-phase extraction, silylation and gas chromatography-mass spectrometry, $J$ Chromatogr A., 1217 (41) 6428-35 (2010). DOI: 10.1016/j.chroma.2010.08.020. 
[12] M. Ding, J. Zou, Rapid micropreparation procedure for the gas chromatographic-mass spectrometric determination of BHT, BHA and TBHQ in edible oils, Food Chem., 131(3) 1051-1055 (2012).

DOI: 10.1016/j.foodchem.2011.09.100.

[13] M. Delgado-Zamarreño, I. González-Maza, A. SánchezPérez, R. Carabias Martínez, Analysis of synthetic phenolic antioxidants in edible oils by micellar electrokinetic capillary chromatography, Food Chem., 100, 1722-1727 (2007). DOI: 10.1016/j.foodchem.2005.10.018.

[14] Y. Guan, Q. Chu, L. Fu, T. Wu, J. Ye, Determination of phenolic antioxidants by micellar electrokinetic capillary chromatography with electrochemical detection, Food Chem., 94 (1) 157-162 (2006). DOI:10.1016/j.foodchem.2005.01.015.

[15] W. Ammawath, Y. B. Che Man, R. B. Abdul Rahman, B. S. Baharin, A FTIR spectroscopic method for determining butylated hydroxytoluene in palm olein and palm oil, J. Am. Oil Chem. Soc., 83(3) 187-191 (2006). DOI: 10.1007/s11746-006-1192-0.

[16] G. K. Ziyatdinova, G. K. Budnikov, A. I. Samigullin, G. T. Gabdullina, A. V. Sofronov, L. A. Al'metkina, I. S. Nizamov, R. A. Cherkasov, Electrochemical determination of synthetic antioxidants of bisdithiophosphonic acids, J. Anal Chem., 65, 1273-1279 (2010). DOI: $10.1134 / \mathrm{S} 1061934810120129$.

[17] L. F. Capitán-Vallvey, M. C.Valencia, E. Arana Nicolás, Solid-phase ultraviolet absorbance spectrophotometric multisensor for the simultaneous determination of butylated hydroxytoluene and co-existing antioxidants, Anal. Chim. Acta., 503, 179-186 (2004).

DOI: 10.1016/j.aca.2003.10.027.

[18] U. Viplava Prasad, T. E. Divakar, K. Hariprasad, C. S. P. Sastry, Spectrophotometric determination of some antioxidants in oils and fats, Food Chem., 25, 159-164 (1987). DOI: 10.1016/0308-8146(87)90065-3.

[19] M. J. Cardone, F. Bosch Reig, P. Campins Falco, Analyst, 115 (1), 111-113 (1990). DOI: $10.1039 / A N 9901500111$.

[20] P. Campins Falco, F. Bosch Reig, J. Verdu Andres, Application of the H-point standard additions method by using absorbance increment values as analytical signals, Talanta, 39 (1) 1-7 (1992).

DOI: 10.1016/0039-9140(92)80042-C.

[21] P. Campins Falco, F. Bosch Reig, J. Verdu Andres, Evaluation and elimination of the "blank bias error" using the H-point standard addition method: Application to spectrophotometric determinations using absorbent blank, Anal. Chim. Acta, 270, 253-265 (1992).

DOI: $10.1016 / 0003-2670(92) 80115-\mathrm{N}$.

[22] F. Bosch Reig, J. Verdu Andres, P. Campins Falco, C. Molins Legua, Study of the behaviour of the absorbent blanks in analytical procedures by using the H-Point standard additions method (HPSAM), Talanta, 41 (1) 39-52 (1994). DOI:10.1016/0039-9140(94)80166-5.

[23] Y. Ni, M. Qi, S. Kokot, Simultaneous spectrophotometric determination of ternary mixtures of tartrazine, sunset yellow, and ponceau $4 \mathrm{r}$ by h-point standard addition method, Anal. Lett., 34 (14) 25852596 (2001). DOI: 10.1081/AL-100107537.
[24] J. Verdu-Andres, F. Bosch-Reig, P. Campins-Falco, Hpoint standard additions method. Part 1. Fundamentals and application to analytical spectroscopy, Analyst, 120 (2) 299-304 (1995).

[25] P. Campins-Falco, J. Verdu-Andres, F. Bosch-Reig, Evaluation and elimination of the blank bias error using the H-point standard additions method (HPSAM) in the simultaneous spectrophotometric determination of two analytes, Anal. Chim. Acta, 348, 39-49(1997). DOI: 10.1016/S0003-2670(97)00230-4.

[26] Theia'a N.Al-Sabha,Nagham N. Habeb, Simultaneous Spectrophotometric Determination of o-Aminophenol and p-Aminophenol Using H-Point Standard Addition Method-Application to Real Waters, Pak. J. Anal. Environ. Chem., 13 (1) 53-62 (2012).

[27] E. A. Basher, M. A. Z. Eltayeb, H-point standard addition method for simultaneous spectrophotometric determination of cobalt (II) and zinc (II) ions, Adv. Anal. Chem., 4 (2) 21-29 (2014). DOI: $10.5923 /$ j.aac.20140402.01.

[28] H. R. Pouretedal, M. Asefi, H-point standard addition method for simultaneous determination of cobalt(II) and zinc(II) ions, Iran. Chem. Soc., 5 (4) 546-552 (2008).

[29] M. M. Issa, R. M. Nejem, A. A. Shanab, N. T. Shaat, Kinetic simultaneous spectrophotometric determination of paracetamol and ibuprofen using H-point standard addition method, J. Chem. Pharm. Res., 4 (7) 35353540 (2012).

[30] R. Hajian, N. Shams, A. Rad, Application of H-point standard addition method for simultaneous spectrophotometric determination of hydrochlorothiazide and propranolol, J. Braz. Chem. Soc., 20 (5) 860-865 (2009). DOI: 10.1590/S0103-50532009000500009.

[31] H. Tavallali, M. Sheikhaei, Simultaneous kinetic determination of paracetamol and caffeine by H-point standard addition method, Afr. J. Pure Appl. Chem., 3 (1) 011-019 (2009).

[32] A. R. Zarei, K. Mardi, S. Chalavi, Simultaneous spectrophotometric determination of tramadol and acetaminophen in pharmaceutical formulations using $\mathrm{H}$ point standard addition method, J. J. Pharm. Sci., 6, 1 (2013). DOI: $10.12816 / 0000362$.

[33] M. Hajimahmoodi, M. R. Oveisi, N. Sadeghi, B. Jannat, E. Nilfroush, Simultaneous Determination of Carmoisine and Ponceau 4R, Food Anal. Methods, 1 (3) 214-219 (2008). DOI: 10.1007/s12161-008-9022-7.

[34] A. Safavi, H. Abdollahi, F. Sedaghatpour, M. R. N. Hormozi, Indirect simultaneous kinetic determination of semicarbazide and hydrazine in micellar media by $\mathrm{H}$ point standard addition method, Talanta, 59 (3) 147-153 (2003). DOI: 10.1016/S0039-9140(02)00465-4.

[35] F.Bosch Reig, P.Campins Falco, H-point standard additions method. Part 1. Fundamentals and application to analytical spectroscopy, Analyst, 113 (7) 1011-1016(1988). DOI: 10.1039/AN9881301011.

[36] F. B. Reig, P. C. Falco, B. H. Hernandez, A. S. Cabeza, Development of the H-point standard additions method for coupled liquid chromatography and UV-visible spectrophotometry, Anal. Chim. Acta, 257, 89-98 (1992). DOI:10.1016/0003-2670(92)80154-Y. 
[37] A. Safavi, H. Abdollahi, Application of the H-point standard addition method to the speciation of $\mathrm{Fe}(\mathrm{II})$ and $\mathrm{Fe}(\mathrm{III})$ with chromogenic mixed reagents, Talanta, 54, 727-734 (2001). DOI: 10.1016/S0039-9140(01)00321-6.

[38] E. Shams, H. Abdollahi, M. Yekehtaz, R. Hajian, Hpoint standard addition method in the analysis by differential pulse anodic stripping voltammetry: $\mathrm{Si}-$ multaneous determination of lead and tin, Talanta, $\mathbf{6 3}$, 359-364 (2004). DOI: 10.1016/j.talanta.2003.11.003.

[39] E. Shams, H. Abdollahi, R. Hajian, Simultaneous determination of copper and bismuth by anodic stripping voltammetry using H-point standard addition method with simultaneous addition of analytes, Electroanal., 17, 1589-1594 (2005). DOI: 10.1002/aelan.200403261.

[40] A. A. Ensafi, R. Hajian, Determination of tryptophan and histidine by adsorptive cathodic stripping voltammetry using H-point standard addition method, Anal. Chim. Acta., 580, 236-243 (2006). DOI: 10.1016/j.aca.2006.07.076

[41] ICH Harmonised Tripartite Guideline, Int. Conf. on Harmonisation of Technical Requirements for Registration of Pharmaceuticals for Human Use "Validation of Analytical Procedure: Methodology", 2003.

[42] A. Golcu, B. Doğan, S. A. Ozkan, Anodic voltammetric behavior and determination of antihistaminic agent: fexofenadine HC, Anal. Lett., 38, 1913-1931 (2005). DOI: $10.1080 / 00032710500230871$

[43] Analytical Procedures and Methods Validation: Chemistry, Manufacturing, and Controls, Federal Register (Notices), 65, 776 (2000)

[44] A. Golcu, New, simple, and validated UVspectrophotometric method for the estimation of some beta blockers in bulk and formulations, Journ. of Anal. Chem., 63, 6, 538-543 (2008). DOI: $10.1134 / \mathrm{S} 106193480806004 \mathrm{X}$.

[45] C. M. Riley, T. W. Rosanske (Eds.). Development and Validation of Analytical Methods. New York: Elsevier Science Ltd., 1996.

[46] D. Tarinc, A. Golcu, Development and validation of spectrophotometric methods for determination of thiamphenicol in capsule forms, KSU. Journ. of Eng. Sci., 14 (1) (2011).

[47] A. Golcu, B. Doğan, S. AOzkan, Electrochemical investigation and determination of the antibacterial Loracarbef by voltammetric methods, Analytical Letters, 42, 689-705(2009). DOI: 10.1080/00032710802678637

[48] S. Eken, M. Özgür, Simultaneous determination of BHA \& BHT in chewing-gum and tomatoes soup by derivative spectrophotometry, $6^{\text {th }}$ Aegean Analytical Chemistry Days, (AACD 2008), Denizli, Turkiye, 9-12 October, 2008, Book of Abstracts, p. 214. 